\title{
INTEGRATED LAND EVALUATION FOR SUSTAINABLE AGRICULTURAL PRODUCTION BY USING ANALYTICAL HIERARCHY PROCESS
}

\author{
AMIN SHARIFIFAR ${ }^{1 *}$, HADI GHORBANI ${ }^{1}$, HAJI KARIMI $^{2}$ \\ ${ }^{1}$ Shahrood University of Technology, Shahrood \\ ${ }^{2}$ Ilam University, Ilam
}

SHARIFIFAR, A. - GHORBANI, H. - KARIM, H.: Integrated land evaluation for sustainable agricultural production by using analytical hierarchy process. Agriculture (Pol'nohospodárstvo), vol. 59, 2013, no. 3, pp. 131-140.

This study discusses sustainable agricultural production by land evaluation based on a multiple criteria approach. The study was carried out in the Bastam region located at the north Shahrood township of Semnan Province in the northeast of Iran. Soil, landscape and climatic data were collected to assess the study area based on its capability for cultivation of apple, tomato, wheat and white potato. Making the final decision for growing the most appropriate crop was based upon three criteria: (1) the physical suitability of the study area for crop cultivation; (2) environmental consideration; (3) economic bene- fit accruing from the production of each crop. The results of the assessment of the above criteria were incorporated using the Analytical Hierarchy Process (AHP) technique. Ultimately, wheat was found to be the most suitable crop for cultivation considering all the criteria in the study area. This study, therefore, was a step taken towards promoting sustainable agriculture by trying to introduce as efficient an approach as possible in land use planning, and selecting the most sustainable ways to put the land to optimum use.

Key words: land use planning; environmental assessment; economic evaluation; Analytical Hierarchy Process

Exhaustive land use planning has been found to reduce the negative impacts brought about by the effects of agricultural practices on natural resources and ecosystems. Of the various agricultural evaluations available in the literature, some people have studied the economic aspects, environmental aspects and some physical suitability in the evaluation of lands, but no one has studied all these aspects simultaneously. Land use planning towards sustainable agriculture can be comprehensive in terms of considering environment and agricultural benefits only when it is conducted on a multiple criteria basis. The decision-adoption process upon agricultural land use is suggested to be carried out by incorporating different criteria in this study. In this research, a kind of integrated approach for agricultural land use planning is used as a case study of multiple criteria analysis for a suitable land utilisation scheme for sustainable agriculture. In this integrated research, three criteria affecting agricultural land use type, including physical suitability of land, environmental vulnerability, and economic profitability were studied in the Abr region, one of the land units located at the north of the study area. The physical evaluation of land determines the suitability of a specific land unit for possible utilisations technically. This is important for maintaining long-term productivity of lands, using them optimally, and not degrading the soil by unsuitable and technically disastrous utilization.

Depending on land quality and capacity, different land units under different agricultural uses show different levels of vulnerability to degradation, chemical contamination and chemical compounds leaching to

Amin Sharififar, MSc. (*Corresponding author), Faculty of Agriculture, Shahrood University of Technology, 36199-95161, Shahrood, Iran. E-mail: ilam amin@yahoo.com

Hadi Ghorbani, PhD., Faculty of Agriculture, Shahrood University of Technology, 36199-95161, Shahrood, Iran. E-mail: Ghorbani1969@yahoo.com

Haji Karimi, PhD., Faculty of Agriculture, Ilam University, Ilam, Iran. E-mail: haji.karimi@gmail.com 
groundwater. Towards attempting to protect environmental safety, the chemical vulnerability of the study area was analysed.

Another major factor which plays a major role in decision making with regard to land use type, is the economic benefit accruing to farmers basing on the type of crop and local commercial cultivation by entrepreneurs.

A proven, reliable technique, Analytical Hierarchy Process (AHP), was applied to incorporate these three criteria. This technique, which has been developed by Saaty (1980, 1994 and 2001) has proved its usefulness in solving problems relating to decision making in multiple criteria, and has been used widely all over the world in decision making in multicriteria situations and in different fields. The AHP technique has been used in environmental assessments and agricultural site selections, but has not been used, or has been very poorly used in agricultural land use planning in terms of crop selection for a given site based on an integrated approach. Relevant studies on environmental sciences and operational management by using AHP have been reviewed recently by Diaz-Baleiro and Romero (2008), Huang et al. (2011), Wu and Barnes (2011) and Subramanian and Ramanathan (2012). Many case studies on multiple criteria decision analysis in subjects similar to the present study are mentioned in those review papers, but none of them are dedicated to sustainable agricultural land use planning and determination of crop types in a specific land unit.

This study seeks to find out the best land use type that incorporates the most technically, economically and environmentally suitable crop by considering these factors simultaneously in each land unit. This study takes a step toward sustainable agricultural planning and management.

\section{MATERIALS AND METHODS}

\section{Study area description}

This study was conducted in the Bastam region of Semnan province located in the northeast of Iran (Figure 1). The study sites were located between $54^{\circ} 39^{\prime}$ and $55^{\circ} 20^{\prime}$ east longitude, and $36^{\circ} 26^{\prime}$ and $36^{\circ} 45^{\prime}$ north latitude. The slope gradient varied from flat land to $8 \%$. The total surface area was about 53,500 ha, but the land unit, which is presented as a sample for de- termining the crop type (crop selection), has a surface area of 8,125 ha. The topography of this land unit is gravelly alluvio-colluvial fans, and there are Piedmont plateaux and alluvial plains in other land units. Aridisols and Entisols are the main soil orders in the region. According to the bioclimatic map of the region (FAO/ UNESCO 1974), the climate in the study area is attenuated subdesert climate. The water requirement of the crops is supplied from ground water by wells. The summary of meteorological data of the study area is presented in Table 1.

\section{Soil sampling and analysis}

Totally, 104 soil profiles were investigated, and among them, 11 representative profiles were selected. Therefore, land mapping units, taxonomically classified to the family level, were segregated. The procedure of taxonomic land classification was according to the soil taxonomy manual of the United States Department of Agriculture (USDA 2010). This classification is based on field surveys and morphological descriptions, like evidence of leaching, soil horizons positions and their depths, and chemical and physical analysis, such as electrical conductivity, organic carbon, exchangeable sodium percentage, cation exchange capacity, carbonate content, texture, structure, and so on. Soil moisture regimes were aridic and torric, and thermal regime was mesic. The sample land unit which is discussed in this paper, belongs to the soil family of loamy skeletal mixed mesic, and is located at the north of the study area. The geographical positions of land mapping units (soil families) of the region are presented in a schematic map in Figure 1. The site characteristics are presented in Table 2.

\section{Physical land suitability evaluation}

In this study, the maximum limitation method in the framework of the Food and Agriculture Organization (1976) is used to evaluate the physical suitability of apple (Malus domestica), white potato (Solanum tuberosum), tomato (Lycopersicum esculentum) and wheat (Triticum aestivum) for cultivation in a specific land unit in the study area. The soil, landscape and climatic characteristics are used for evaluation, and matched with reference tables; for example, in Sys et al. (1993), their scores are evaluated, and the lowest score (the most limiting one) is reported as the physical land index for every usage type in one land unit. 


\section{Economic evaluation}

The economic assessment of different crop cultivations in this study is based on calculation of output prices, input costs and net income by a special currency. The economic index, considered for evaluation, is the net profit of each crop to determine which is the most profitable crop to cultivate in the land unit of Abr. The miscellaneous heads relating to costs for every crop cultivation is investigated, then the total cost is subtracted from the total price of a specific crop and, thereby, the net return is obtained. Mean yield of more than a 5-year period of the selected crops per hectare is multiplied by the unit price of crops to obtain the total price of each crop per hectare.

The economic investigations of crop cultivation costs and prices were implemented in the Agricultural Planning and Economic Research Institute in the Ministry of Jihad-e-Agriculture by distributing questionnaires among representative farmers (Ministry of Agriculture 2003).

\section{Environmental assessment}

In this study, the environmental investigation is carried out from an agricultural point of view. As environmental impact, the susceptibility of soil to contamination, and in the next step its vulnerability to excessive chemicals leaching into groundwater, is assessed for each crop cultivation by using the Arenal model within the MicroLEIS software package. The Arenal model is an expert system for qualitative evaluation of land vulnerability to agrochemical compounds. The compounds leaching through the soil profile, and the subsequent pollution of groundwater is evaluated for different land management systems. The Arenal model also determines the vulnerability of groundwater, especially to nitrates and pesticide leaching at a regional scale. The intrinsic properties of soil, climate data and management systems are used for the analysis. The input data for the model are: precipitation, topography, depth of water table, soil texture, salinity, $\mathrm{pH}$, exchange capacity, crop system, using or not using artificial drainage and water extraction. There are four classes in the model output. V1: no vulnerability; V2: slight vulnerability; V3: moderate vulnerability; V4: severe vulnerability. More complete information on MicroLEIS models can be found in De la Rosa et al. (1992, 2004, 2009).

\section{Analytical hierarchy process}

The analytical hierarchy process is a method that formulates and analyses decisions by decomposing a complex multicriteria decision-making problem into a hierarchy of criteria and a set of alternatives. This technique is based on pairwise comparisons, and provides the possibility of considering quantitative and qualitative criteria, and also an analysis of sensitivity of criteria and consistency of decisions made by pairwise comparison matrices. The alternatives are com-

T

Temperature and precipitation data of the study area

\begin{tabular}{|l|c|c|c|c|c|}
\hline Season & Months & $\mathrm{T} / \mathrm{m}\left[{ }^{\circ} \mathrm{C}\right]^{1}$ & $\mathrm{~T} / \mathrm{max}\left[{ }^{\circ} \mathrm{C}\right]^{2}$ & $\mathrm{~T} / \mathrm{min}\left[{ }^{\circ} \mathrm{C}\right]^{3}$ & $\mathrm{P}[\mathrm{mm}]^{4}$ \\
\hline \multirow{4}{*}{ Winter } & December & 3.6 & 8.2 & -1.0 & 16.7 \\
& January & 1.7 & 6.1 & -2.7 & 18.0 \\
& February & 3.8 & 8.8 & -1.3 & 18.3 \\
\hline \multirow{4}{*}{ Spring } & March & 8.5 & 14.1 & 2.8 & 29.6 \\
& April & 14.8 & 21.1 & 8.5 & 25.0 \\
\hline \multirow{4}{*}{ Summer } & May & 19.6 & 26.3 & 13.0 & 4.7 \\
& June & 24.2 & 31.0 & 17.5 & 2.3 \\
\hline \multirow{4}{*}{ Autumn } & July & 26.7 & 33.1 & 20.3 & 1.5 \\
& August & 25.8 & 21.4 & 19.1 & 2.8 \\
\hline Annual & September & 21.9 & 29.0 & 14.8 & 6.2 \\
\hline
\end{tabular}

${ }^{1}$ Mean temperature; ${ }^{2}$ mean maximum temperature; ${ }^{3}$ mean minimum temperature; ${ }^{4}$ precipitation 
pared in a pairwise manner in regard to each criterion, then preferences are made among alternatives. Figure 2 gives a better realisation of the study procedure. There are three main stages in multiple criteria decision making through AHP, including building a hierarchy structure, calculation of weights by comparison matrices and analysis of consistency of the system. One advantage of the AHP technique is the possibility of checking the consistency of the decision, and its reliability or unreliability. Every pairwise comparison matrix can be consistent or inconsistent. The consistency or reliability of a judgment can be investigated through an inconsistency index. As Saaty (1980) says, 'when the inconsistency ratio is less than 0.1 , the de- cision and judgments are reliable'. The Inconsistency Index formula is as follows

$$
\text { Inconsistency Index }=\left(\kappa_{\max }-n\right) / n-1
$$

where, $K_{\max }$ is the greatest weight in the AHP-normalised matrices, $\mathrm{n}$ is the number of criteria. Inconsistency ratio is calculated using the following formula:

$$
\text { Inconsistency ratio }=\text { I. I / I. I. R }
$$

where, I.I is the final inconsistency index of judgments, and I.I.R is the inconsistency index of a random matrix which has already been calculated in tables in the AHP-related literature. Complete information on the principles of the AHP can be found in Saaty (1980) and Ghodsipour (2012).

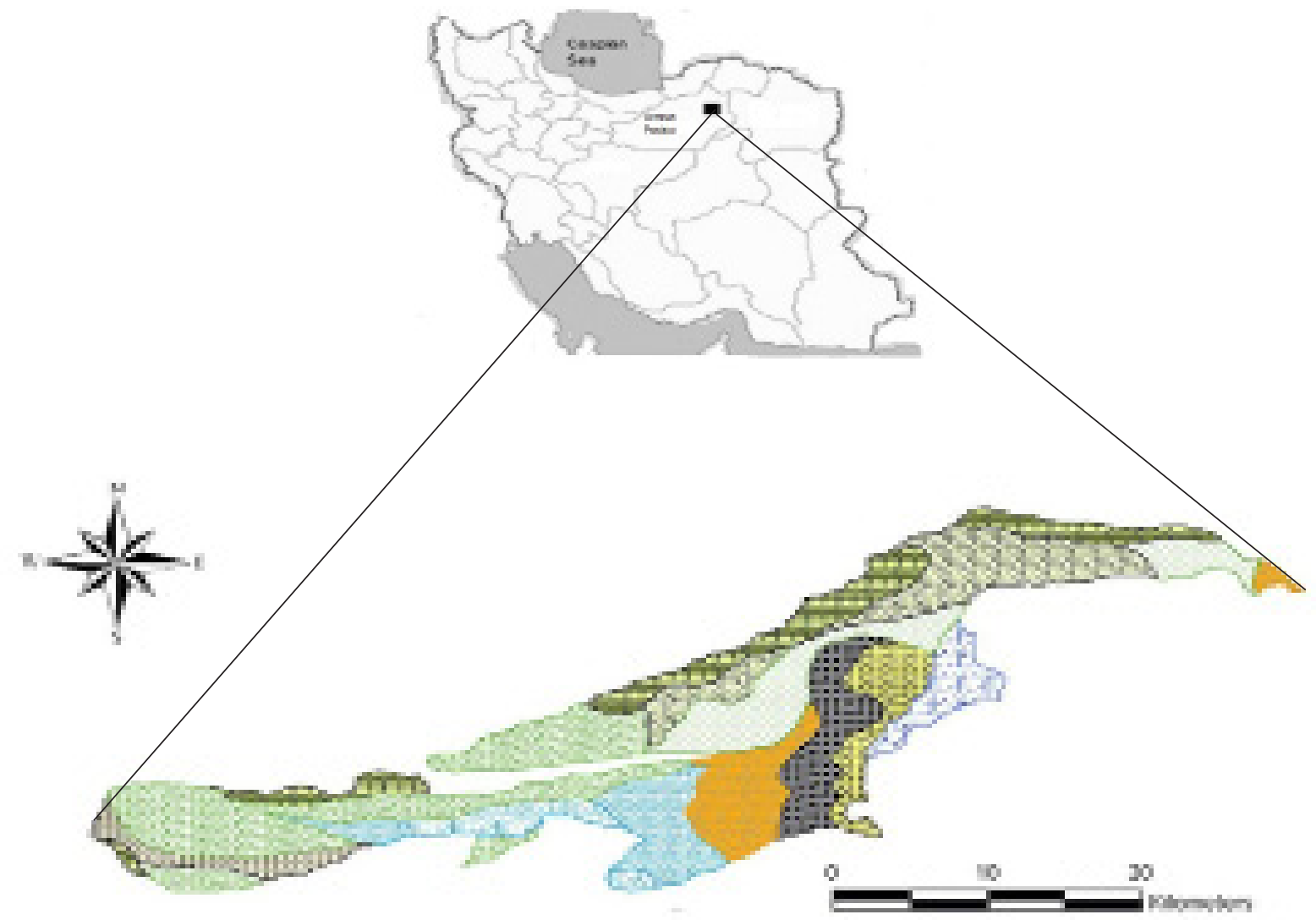

\section{Ardl tandit:}

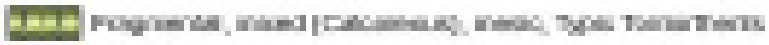

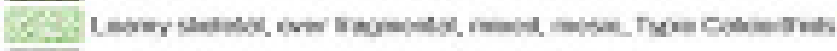

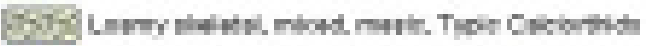

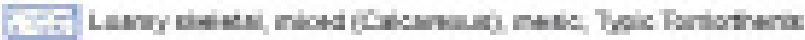

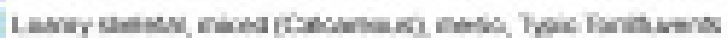

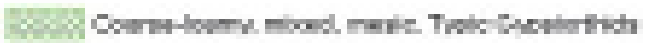

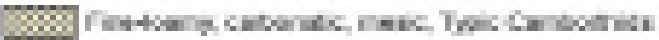

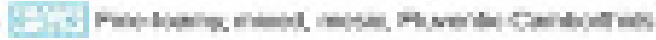

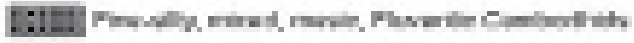

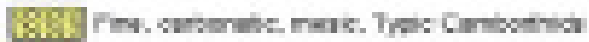

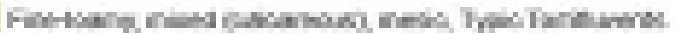

Figure 1. Taxonomic classification of the study area soils 


\section{RESULTS AND DISCUSSION}

\section{Results of evaluation of physical suitability}

Tables 3 and 4 show the soil and climate characteristics, as well as their scores for each crop (utilisation type). Wheat was found to be the most suitable crop for the studied land unit. The maximum limitation method is a simple method and more objective than other methods, such as parametric methods, since we are not certain about the definite relations and interactions among characteristics. Characteristics used in this study for land evaluation are internationally accepted criteria, as have been confirmed by FAO (1976), and have been widely used by researchers, such as Boix and Zinck (2008) and Mendas and Delali (2012), in land evaluation.

Investigation of climatic characteristics showed no significant limitation for any of the four crops. The study area soil has a high amount of $\mathrm{CaCO}_{3}$ due to its natural geological and pedological instead of paedological situations. This characteristic mitigates the yield of several crops. For example, in this study, the physical suitability of apple, potato and tomato show a low rating as presented in Table 3. Some examples of land suitability studies in agriculture are by Kalogirou (2002), which tried to implement a land suitability model and have used the physical FAO (1976) land classification for crops, then performed a suitability classification for wheat, barley, maize, seed cotton and sugar beet. Ceballos-Silva and Lopez-Blanco (2003) evaluated the suitability of lands for maize and potato in Mexico, and compared actual and potential areas for maize and potato cultivation; and Boix and Zinck (2008) discussed the physical land suitability and evaluated land use options to support crop diversification. The common aspect in the studies by all physical land evaluators is that they usually try to classify studied lands in terms of physical suitability for selected crops. Although the physical evaluation of land shows the potentialities and restrictions of land for selected purposes, and helps in minimising land degradation that is usually caused by unscientific uses, but most of the researchers of this subject have not determined a certain agroecological utilisation type that guarantees sustainable agricultural production which considers safety and sustainability of natural resources. Because they mostly do not consider multiple effective factors, such as environmental sustainability and safety, as well as economic matters or, if some do so, they do not incorporate those multiple factors for decision making in land use and management.

\section{Results of economic evaluation}

The economic evaluation in respect to apple was different from the other three crops, in the sense that apple is a perennial crop and has varying growing periods. About 8 years are needed for apple to reach the stage of economic yield. However, there are expenses during these first 8 years of plantation, and expenses during the economic return period. The advantageous

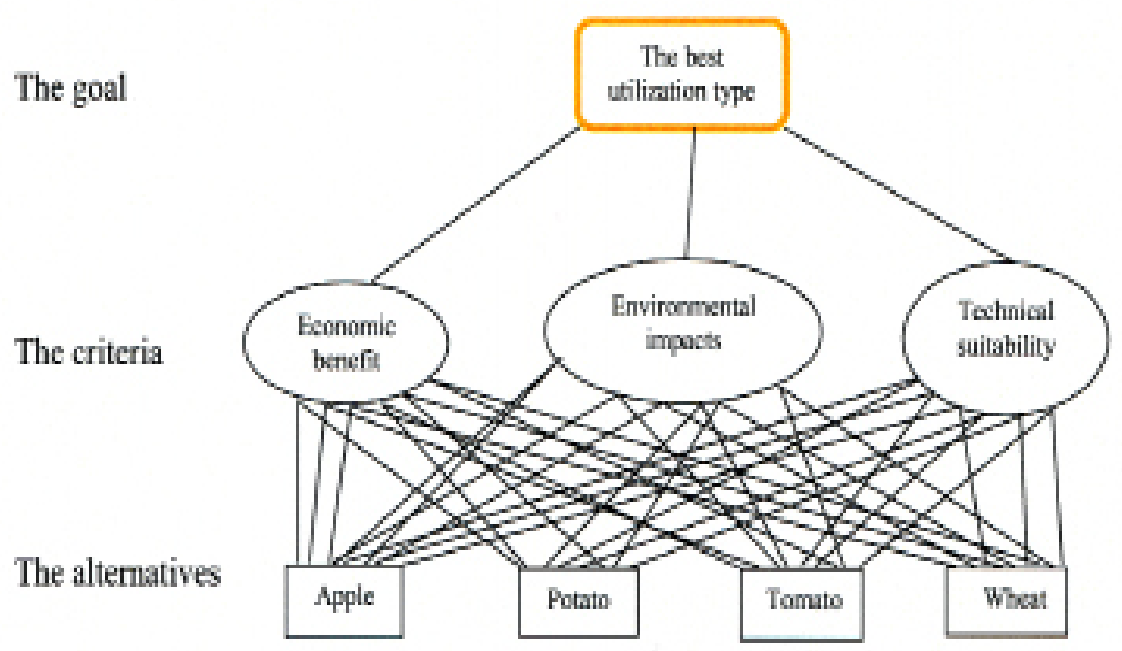

Figure 2. Hierarchy of the study procedure 
life span of apple trees is 30 years, as has been studied in the country. For this crop, the total expenses in the first 8 years is divided by 30 , and the obtained value is considered as the fixed mean annual expense during the economic return period (after 8 years). This value is added to the annual expenses of the economic yielding period, and the summation is considered as the total annual cost of apple production.

Table 5 gives a list of costs and prices for annual crops, including potato, tomato and wheat, and Tables 6 and 7 show the costs and price of apple. Tomato was found to be the most beneficial crop; this is because of its comparatively high yield despite its low physical suitability index. Costs of cultivating tomato are comparatively lower than apple. Apple production expenses are the highest, and the yield is relatively low because of poor soil suitability. The land tenure and cost of water have not been taken into consideration. Usually, farmers do not have to pay for irrigation water. Markets and places of trade are the same for all the crops since we aim to decide upon a given land unit, in which mentioned crops are to be compared for cultivation in order to optimise land use. Fluctuations of prices and costs, as well as factors affecting crop sales, have also been considered as identical and invariable. The prices and costs in this study are valid for 2000-2001.

In the literature, researches focusing on economic evaluations besides physical evaluation in agriculture, are relatively scanty. This is probably due to the difficulties and complexity of economic evaluation. Another reason could be the lack of farmers ' cooperation with researchers. For example, Boix and Zinck (2008), in explaining the reason why they could not implement economic evaluation besides physical evaluation, state that the local farmers did not cooperate with them in answering the questionnaires. There are some studies relevant to economic analyses, such as that of Erdal et al. (2007) which focused on energy use in sugar beet production in Turkey, and aimed at energy input and

T a b 1 e 2

Mean values of the representative soil profile characteristics

\begin{tabular}{|c|c|c|c|c|c|c|c|c|c|c|}
\hline $\begin{array}{l}\text { Land } \\
\text { unit }\end{array}$ & $\begin{array}{c}\text { Texture } \\
\text { class }\end{array}$ & $\begin{array}{c}\text { Slope } \\
{[\%]}\end{array}$ & $\begin{array}{c}\text { Stoniness } \\
{[\%]}\end{array}$ & $\begin{array}{c}\text { Drainage } \\
\text { class }\end{array}$ & $\mathrm{pH}$ & $\begin{array}{l}\text { Rooting } \\
\text { depth } \\
{[\mathrm{cm}]}\end{array}$ & $\mathrm{ESP}^{1}$ & $\begin{array}{c}\text { Carbonate } \\
\text { content } \\
{[\%]}\end{array}$ & $\begin{array}{c}\text { Electrical } \\
\text { conductivity } \\
{[\mathrm{ds} / \mathrm{m}]}\end{array}$ & $\begin{array}{l}\text { O.C } \\
{[\%]^{2}}\end{array}$ \\
\hline Abr & $\begin{array}{l}\text { Sandy } \\
\text { loam }\end{array}$ & $0-5$ & $15-35$ & Good & 7.85 & 95 & 2.7 & 31 & 0.4 & 0.4 \\
\hline
\end{tabular}

${ }^{1}$ Exchangeable sodium percentage; ${ }^{2}$ organic carbon percentage

$\mathrm{T}$ a $\quad \mathrm{b} \quad 1$ e 3

Suitability scores of each soil characteristic for cultivation of the crops in the specified land unit

\begin{tabular}{|c|c|c|c|c|}
\hline Soil characteristics & Apple & Potato & Tomato & Wheat \\
\hline Texture & 61.66 & 85.00 & 85.00 & 60.00 \\
\hline O. $\mathrm{C}^{1}$ & 60.00 & 50.00 & 50.00 & 85.00 \\
\hline $\mathrm{pH}$ & 80.83 & 63.75 & 67.50 & 90.00 \\
\hline $\mathrm{CaCO}_{3}$ & 36.40 & 38.66 & 32.00 & 82.50 \\
\hline $\mathrm{ESP}^{2}$ & 93.25 & 99.10 & 98.30 & 99.10 \\
\hline Slope & 98.40 & 96.25 & 96.25 & 96.25 \\
\hline Soil rooting depth & 93.00 & 100.00 & 80.00 & 100.00 \\
\hline $\mathrm{EC}^{3}$ & 99.00 & 98.00 & 99.30 & 98.00 \\
\hline
\end{tabular}

${ }^{1}$ Organic carbon percentage; ${ }^{2}$ exchangeable sodium percentage; ${ }^{3}$ electrical conductivity 
output evaluation and efficiency of input energy consumption to conduct a cost analysis. Mohammadi et al. (2008) performed a similar study on potato production in Iran. Their concentration was on finding out the proportionate costs of different input items. Samranpong et al. (2009) investigated the economic land evaluation for agricultural resource management, which aimed to build a model to carry out economic land evaluation based on physical land evaluation, and stated that this model of economic evaluation is helpful for decision makers due to the resultant economic returns of land use.

\section{Results of environmental assessment}

Results of the Arenal model showed that there is a difference in vulnerability of land to chemical con-

$\mathrm{T}$ a

Climatic data and their scores

\begin{tabular}{|l|c|c|c|c|}
\hline \multicolumn{1}{|c|}{ Climatic characteristics } & Apple & Potato & Tomato & Wheat \\
\hline Mean temperature of the growing cycle $\left[{ }^{\circ} \mathrm{C}\right]$ & $19.7(95.0)^{1}$ & $24.6(79.6)$ & $19.5(92.5)$ & $12.4(85.7)$ \\
Mean temperature of the vegetative stage $\left[{ }^{\circ} \mathrm{C}\right]$ & - & - & $14.8(77.5)$ & $5.0(72.5)$ \\
Mean temperature of the flowering stage $\left[{ }^{\circ} \mathrm{C}\right]$ & $14.8(81.8)$ & - & - & $14.8(95.0)$ \\
Mean temperature of the ripening stage $\left[{ }^{\circ} \mathrm{C}\right]$ & - & - & $24.2(66.6)$ & $25.45(92.6)$ \\
Average min temperature of the $1{ }^{\text {st }}$ month $\left[{ }^{\circ} \mathrm{C}\right]$ & - & $17.5(95.0)$ & - & - \\
Average min temperature of three other months $\left[{ }^{\circ} \mathrm{C}\right]$ & - & $18.0(95.0)$ & - & - \\
Average temperature difference between day and night ${ }^{2}\left[{ }^{\circ} \mathrm{C}\right]$ & - & $13.4(95.0)$ & $13.3(50.0)$ & - \\
Average daily min temperature of the coldest $\operatorname{month}\left[{ }^{\circ} \mathrm{C}\right]$ & - & - & - & $-2.7(95.0)$ \\
Average daily max temperature of the coldest $\operatorname{month}\left[{ }^{\circ} \mathrm{C}\right]$ & - & - & - & $6.1(95.0)$ \\
Mean temperature of the coldest month $\left[{ }^{\circ} \mathrm{C}\right]$ & $9.0(95.0)$ & - & - & - \\
Relative humidity of the growing cycle $[\%]$ & $42.4(95.0)$ & - & $41.3(95.0)$ & - \\
\hline
\end{tabular}

${ }^{1}$ Values in the parenthesis are suitability scores and the values outside the parenthesis are climatic data; ${ }^{2}$ average temperature difference between day and night is calculated for the flowering stage of tomato and for the growing cycle of potato

$\mathrm{T}$ a

Costs and prices of the crops (in US\$)

\begin{tabular}{|c|c|c|c|}
\hline Type of costs, price & Potato & Tomato & Wheat \\
\hline Chemical manure & 10.32 & 28.05 & 9.55 \\
\hline Animal manure & 0.29 & 24.77 & 0.04 \\
\hline Pesticide and herbicide & 6.04 & 8.07 & 2.38 \\
\hline Seed & 148.29 & 32.97 & 12.28 \\
\hline Labour & 115.68 & 204.47 & 26.87 \\
\hline Machinery & 49.62 & 105.46 & 29.38 \\
\hline Packing and miscellaneous & 16.20 & 74.95 & 0.28 \\
\hline Total sum & 346.44 & 478.74 & 80.78 \\
\hline Unit price [per kilogram] & 0.04 & 0.03 & 0.05 \\
\hline Yield [kg] & $15,000.00$ & $25,000.00$ & $2,500.00$ \\
\hline Total gross profit [per hectare] & 600.00 & 750.00 & 125.00 \\
\hline Total net profit [per hectare] & 253.56 & 271.26 & 44.22 \\
\hline
\end{tabular}


tamination in respect of annual and perennial crops. Table 8 shows the results. The land under perennial crop cultivation (apple) shows more vulnerability to soil contamination than annual crops (potato, tomato and wheat). The vulnerability classes $\left(\mathrm{V}_{1}-\mathrm{V}_{4}\right)$ were quantified to be used for AHP comparisons. A rating from 0 to 100 was determined by allocating four limits of 25 to each class. For example, the class $\mathrm{V}_{1}$ has a rate in the range of 75-100. The mean value of this range, 87.5 , was reported as the vulnerability rating for annual crops of the class $\mathrm{V}_{1}$, and in the class $\mathrm{V}_{2}$, it was $50-75$, the mean value 62.5 was reported for apple cul- tivation. According to these results, when the studied land unit goes under annual crop cultivation, it is not vulnerable to chemical degradation from agricultural activities, and the risk of soil and water table contamination is very low. Soils included in this class have a very high capacity for retention of agrochemical compounds, and their leaching is very low. Likewise, when the studied land unit is allocated to perennial crops (apple), the vulnerability to agrochemical compounds, in terms of soil and water contamination is low, and the leaching ranges from moderate to high. This difference in chemical vulnerability is due to the different

T

Cost of apple production before economic return period (in US\$)

\begin{tabular}{|l|c|}
\hline Type of costs & Value \\
\hline Chemical manures & 177.54 \\
Animal manure & 68.60 \\
Pesticide & 209.48 \\
Labour & 616.15 \\
Machinery & 624.15 \\
Tools and instruments & 54.00 \\
Saplings & 33.15 \\
Total sum of expenses before economic return period & $1,783.07$ \\
Mean annual expense for economic return period & 59.44 \\
\hline
\end{tabular}

T $\quad$ a

Costs and prices of apple production in the economic return period (in US\$)

\begin{tabular}{|l|r|}
\hline Type of items & Value \\
\hline Chemical manure & 16.13 \\
Animal manure & 4.56 \\
Pesticides & 79.73 \\
Labor & 197.63 \\
Machineries & 49.50 \\
Packing and materials & 200.95 \\
Tools and instruments & 9.31 \\
Total sum & 557.81 \\
Unit price [per kg] & 0.06 \\
Yield [kg] & $12,000.00$ \\
Total gross profit [per hectare] & 720.00 \\
Net profit in the economic return period [per hectare] & 102.75 \\
\hline
\end{tabular}


$\begin{array}{llllllll}T & a & b & 1 & \text { e } & 8\end{array}$

The Arenal model results

\begin{tabular}{|c|c|}
\hline Land use type & $\begin{array}{c}\text { Chemical vulnerability } \\
\text { class }\end{array}$ \\
\hline Wheat & $87.5(\mathrm{~V} 1)$ \\
Potato & $87.5(\mathrm{~V} 1)$ \\
Tomato & $87.5(\mathrm{~V} 1)$ \\
Apple & $62.5(\mathrm{~V} 2)$ \\
\hline
\end{tabular}

management methods applied for annual and perennial crops cultivation, and the different natural attributes of trees and annual crops. Some other researchers, such as De la Rosa et al. (2009) and Shahbazi and Jafarzadeh (2010), have used the Arenal model in land evaluation, and proved its applicability and usefulness.

\section{Results of incorporation of the criteria}

After analysing pairwise comparison matrices for the three criteria, and adding up the relative weights of each alternative, the final rate of each alternative was calculated. In this study, it has been assumed that all the criteria have the same significance and weight. Wheat gave the highest rate (0.935) among all, after which came apple (0.900); both were found to be the most suitable crops. Therefore, wheat cultivation was found to be the most suitable crop with regard to physical, economic and environmental criteria for the studied land unit.

Since these criteria are not homogeneous, and they do not have the same unit of measurement, they cannot be incorporated unless a decision support tool, such as the AHP technique is applied. Researchers can apply this technique without any expert knowledge. The inconsistency ratio of the results in this study was a low value (less than 0.1 ), which shows that the analyses are consistent and reliable.

Towards sustainable agriculture, some studies, such as Rezaei-Moghadam and Karami (2008) have been organised by using AHP, that discussed the features of sustainable agricultural development by using AHP, and the study by Demirel et al. (2009) which discussed AHP and Analytic Network Process (ANP) to determine land cover policies. Nevertheless, none of these researchers studied lands with the aim of selecting suitable crops.

\section{CONCLUSIONS}

This research tried to introduce a neglected approach in decision making on land use type which considers multiple criteria, such as environmental, economic and technical (physical land evaluation) aspects concomitantly. This study was a small step taken towards achieving sustainable agricultural development and use of natural invaluable land resources by trying to choose the ideal crop for optimum agricultural land utilisation.

The applicability of multiple-criteria land use planning was investigated on an integrated basis.

Results of physical land suitability assessment showed that wheat, with the highest land index value, has the highest suitability for cultivation in the studied land unit.

Results of environmental assessment by using the Arenal model showed that apple cultivation results in highest chemical impairments in the studied land unit.

Result of evaluation of relative economic profitability of apple, tomato, wheat and white potato revealed that economically, tomato is the most beneficial crop.

After investigation of apple, tomato, wheat and white potato for being cultivated in one of the study land units, wheat was found to be the most suitable crop with regard to the three criteria mentioned.

These kinds of approaches in agricultural land use planning help in maintaining lands for future generations and in meeting current demands.

Acknowledgements. The authors would like to thank the Soil and Water Research Institute of the Ministry of Agriculture, and the Organization of Agriculture of Bastam County, for cooperating in delivering relative data used in this research.

\section{REFERENCES}

BOIX, L.R. - ZINCK, J.A. 2008. Land-use planning in the Chaco Plain (Burruyacu, Argentina). Part 1: Evaluating land-use options to support cop diversification in an agricultural frontier area using physical land evaluation. In Environmental Management, vol. 42, no. no. 2, pp. 1043-1063. DOI: 10.1007/s00267-0089208-1. 
CEBALLOS-SILVA, A. - LOPEZ-BLANCO, J. 2003. Delineation of suitable areas for crops using a Multi-Critera Evaluation approach and land use/ cover mapping: a case study in Central Mexico. In Agricultural Systems, vol. 77, no. 2, pp. 117-136. DOI: $10.1016 / \mathrm{s} 0308-521 \times(02) 00103-8$.

De la ROSA, D. - ANAYA-ROMERO, M. - DIAZ-PEREIRA, E. - HEREDIA, N. - SHAHBAZI, F. 2009. Soil-specific agro-ecological strategies for sustainable land use-a case study by using MicroLEIS DSS in Sevilla Province (Spain). In Land Use Policy, vol. 26, no. 4, pp. 1055-1065. DOI: 10.1016/j.landusepol.2009.01.004.

De la ROSA, D. - MAYOL, F. - DIAZ-PEREIRA, E. FERNANDEZ, M. - De la ROSA, Jr.D. 2004. A land evaluation decision support system (MicroLEIS DSS) for agricultural soil protection with special reference to the Mediterranean region. In Environmental Modelling \& Software, vol. 19, no. 10, pp. 929-942. DOI: $10.1016 /$ j.envsoft.2003.10.006.

De la ROSA, D. - MORENO, J.A. - GARCIA, L.V. ALMORZA. J. 1992. MicroLEIS: A microcomputerbased Mediterranean land evaluation information system. In Soil Use and Management, vol. 8, no. 2, pp. 89-96. DOI: 10.1111/j.1475-2743.1992.tb00900.x.

DeMIREL, T. - MUSDAL, H. - DeMIREL, N.C. YUCENUR, G.N. 2009. Multi-criteria evaluation of land cover policies using fuzzy AHP and fuzzy ANP: The case of Turkey. In Human and Ecological Risk Assessment, vol. 15, no. 4, pp. 746-764. DOI: $10.1080 / 10807030903051168$.

DIAZ-BALTEIRO, L. - ROMERO, C. 2008. Making forestry decisions with multiple criteria: A review and an assessment. In Forest Ecology and Management, vol. 255 , no. 8-9, pp. 3222-3241. DOI: $10.1016 /$ j. foreco.2008.01.038.

ERDAL, G. - ESENGUN, K. - ERDAL, H. - GUNDUZ, O. 2007. Energy use and economical analysis of sugar beet production in Tokat province of Turkey. In Energy, vol. 32, no. 1, pp. 35-41. DOI: 10.1016.j.energy.2006.01.007.

FAO (Food and Agriculture Organization) 1974. Soil Map of the World, Revised 1988. Paris: UNESCO.

FAO (Food and Agriculture Organization) 1976. A framework for land evaluation. FAO Soils Bulletin 32, Rome. ISBN 92-5-100111-1.

GHODSIPOUR, S.H. 2012. Analytical hierarchy process. Iran, Tehran: Amir Kabir University of Technology Publications (In Persian). ISBN 978-964-463-056-9.

HUANG, I.B. - KEISLER, J. - LINKOV, I. 2011. Multicriteria decision analysis in environmental sciences: Ten years of applications and trends. In Science of the Total Environment, vol. 409, no. 19, pp. 3578-3594. DOI: 10.1016/j.scitotenv.2011.06.022.

KALOGIROU, S. 2002. Expert systems and GIS: an application of land suitability evaluation. In Computers, Environment and Urban Systems, vol. 26, no. 2-3, pp. 89-112. DOI: 10.1016/s01989715(01)00031-x.

MENDAS, A. - DELALI, A. 2012. Integration of Multicriteria Decision Analysis in GIS to develop land suitability for agriculture: Application to durum wheat cultivation in the region of Mleta in Algeria. In Computers and Electronics in Agriculture, vol. 83, pp. 117-126. DOI: 10.1016/j.compag.2012.02.003.

Ministry of Agriculture. 2003. A study of comparative advantage in selected agricultural commodities. Tehran, Iran: Agricultural Planning and Economic Research Institute (APERI). 496 pp. ISBN 964-554916-7.

MOHAMMADI, A. - TABATABAEEFAR, A. - SHAHIN, S. - RAFIEE, S. - KEYHANI, A. 2008. Energy use and economical analysis of potato production in Iran a case study: Ardabil province. In Energy Conversion and Management, vol. 49, no. 12, pp. 3566-3570. DOI: $10.1016 /$ j.econman.2008.07.003.

REZAEI-MOGHADAM, K. - KARAMI, E. 2008. A multiple criteria evaluation of sustainable agricultural development models using AHP. In Environment, Development and Sustainability, vol. 10, no. 4, pp. 407-426. DOI: 10.1007/s10668-006-9072-1.

SAATY, T.L. 1980. The analytic hierarchy process. New York: McGraw Hill International Book Company. 287 pp. ISBN 0-07-054371-2.

SAATY, T.L. 1994. Highlights and critical points in the theory and application of the analytical hierarchy process. In European Journal of Operational Research. vol. 74, no. 3, pp. 426-447. DOI: 10.1016/03772217(94)90222-4.

SAATY, T.L. 2001. Decision making for leaders: The analytic hierarchy process for decision in a complex world, vol. 2. Pittsburgh: RWS Publications. 323 pp. ISBN 096203178x.

SAMRANPONG, C. - EKASINGH, B. - EKASINGH, M. 2009. Economic land evaluation for agricultural resource management. In Environmental Modelling and Software, vol. 24, no. 12, pp. 1381-1390. DOI: 10.1016/j.envsoft.2009.07.004.

SHAHBAZI, F. - JAFARZADEH, A.A. 2010. Integrated assessment of rural lands for sustainable development using MicroLEIS DSS in West Azerbaijan, Iran. In Geoderma, vol. 157, no. 3-4, pp. 175-184. DOI: 10.1016/j.geoderma.2010.04.010.

SUBRAMANIAN, N. - RAMANATHAN, R. 2012. A review of applications of Analytic Hierarchy Process in operations management. In International Journal of Production Economics, vol. 138, no. 2, pp. 215-241. DOI: $10.1016 /$ j.ijpe.2012.03.036.

SYS, C. - VAN RANST, E. - DEBAVEYE, J. 1993. Land evaluation. Part 3: Crop requirements. Brussels: Agricultural Publications 7,3. General Administration of Development Cooperation of Belgium. 199 p.

USDA 2010. Keys to Soil Taxonomy. $11^{\text {th }}$ edition. Soil Survey Staff, United States Department of Agriculture: Natural Resources Conservation Service. Washington, DC. 344 pp. ISBN: 016085427X.

WU, C. - BARNES, D. 2011. A literature review of decision-making models and approaches for partner selection in agile supply chains. In Journal of Purchasing \& Supply Management, vol. 17, no. 4, pp. 256-274. DOI: 10.1016/j.pursup.2011.09.002.

Received: June $26^{\text {th }}, 2013$ 